\title{
DRY MATTER YIELD OF DIFFERENT VARIETIES OF DACTYLIS GLOMERATA AND FESTUCA PRATENSIS
}

\author{
Jacek Sosnowski ${ }^{1}$, Kazimierz Jankowski ${ }^{1}$, Piotr Domański' ${ }^{2}$, Dorota Herda ${ }^{1}$ \\ 1 Siedlce University of Natural Sciences and Humanities, Prusa 14, 08-110 Siedlce, Poland, e-mail: jacek. \\ sosnowski@uph.edu.pl; kazimierz.jankowski@uph.edu.pl; laki@uph.edu.pl \\ 2 The Research Centre for Cultivar Testing in Słupia Wielka, 63-022 Słupia Wielka, Poland, e-mail: p.domanski@ \\ coboru.pl
}

Received: 2015.03.18

Accepted: 2015.06 .02

Published: 2015.07.01

\begin{abstract}
The aim of this paper is to analyze yield variation of Dactylis glomerata and Festuca pratensis varieties grown on organic and mineral soil. This paper has drawn on two field experiments set up and carried out between 2010 and 2013. The experiment was conducted in two experimental stations: one in the Research Centre for Cultivar Testing in Krzyżewo and the other in the Experimental Stations for Variety Testing in Uhinin. The experiment in Krzyżewo was set up on ploughed soil, with spring barley as a forecrop. In Uhnin the experimental plots were located on peat meadow. The experimental plots were sown with varieties of Dactylis glomerata: Niva, Tukan, Amila, Crown Royale and with varieties of Festuca pratensis: Limosa, Pasja, Anturka, Amelka. The full exploitation of Dactylis glomerata varieties was due between 2012 and 2013, whereas for Festuca pratensis it was due between 2011 and 2012. In the experimental plots with the varieties of Dactylis glomerata the grass was harvested six times a year and chemical analysis of the biomass was done taking dry matter only from five cuts. The varieties of Festuca pratensis were harvested four times. Each year in the course of the experiment fresh and dry matter of each cut were weighed. The grass species and their varieties as well as the particular mowing and kind of soil where the grass was grown have an impact on the yield. On mineral soil the yield of Dactylis glomerata was higher than Festuca pratensis. On organic soil the yield of both species was similar. During the two years of experiment the highest yield among Festuca pratensis varieties was noted for Amelka whereas among varieties of Dactylis glomerata the yield was similar and differences were not statistically significant.
\end{abstract}

Keywords: yield, variation, grass, Dactylis glomerata, Festuca pratensis.

\section{INTRODUCTION}

Dactylis glomerata and Festuca pratensis are considered to be of major economic importance because of their variable uses as well as durability, vitality, their modest soil requirements and their tolerance to moderate drought stress [Kasperczyk 1994, Kozłowski, Swędrzyński 1997, Grzegorczyk, Gołębiewska 2004, Borawska-Jarmułowicz, 2006, Czyż et al. 2012]. According to BorawskaJarmułowicz [2011], the yield of different varieties of those grasses is determined by their morphological and biological features and, in particular, according to Rutkowska et al. [1994], by their ability to develop vegetative and reproductive shoots. According to Domański [1997], because of economic and agricultural needs a new variety of a fodder grass should give profitable seed production, high dry matter yield and should provide a farm with good quality fodder. Fodder grass like Dactylis glomerata, grown as temporary grass, can give a yield of over $15 \mathrm{t}$ of dry matter per hectare provided that plants will have a sufficient amount of water and nutrients.

The aim of this paper is to analyze yield variation of Dactylis glomerata and Festuca pratensis varieties grown on organic and mineral soil. 


\section{MATERIAL AND METHODS}

This paper has drawn on two field experiments set up and carried out between 2010 and 2013 by the Research Centre for Cultivar Testing in Słupia Wielka. The experiment was conducted in two experimental stations: one in the Research Centre for Cultivar Testing in Krzyżewo and the other in the Experimental Stations for Variety Testing in Uhinin, being a branch of the Research Centre for Cultivar Testing in Cicibor Duży. The stations are located in the Podlaskie Woivodeship, the Wysokie Mazowiekie county, in the commune of Sokoły. Uhnin is located in the Lubelskie Voivodeship, the Parczew county and the Dębowa Kłoda commune.

The experiment was arranged and conducted according to Research Centre for Cultivar Testing guidelines [Domański 1998]. The experimental plots were sown with varieties of Dactylis glomerata: Niva, Tukan, Amila, Crown Royale and with varieties of Festuca pratensis: Limosa, Pasja, Anturka, Amelka (e. AND 1009).

The plots were randomly selected, 1.5 meters wide and $6.67 \mathrm{~m}$ long, with an area of $10 \mathrm{~m}^{2}$, grouped in blocks with four replications. They were separated by 1 meter pathways between blocks and with 0.5 meter pathways between subblocks. The pathways lay fallow. The experiment in Krzyżewo was set up on ploughed soil, with spring barley as the forecrop. In Uhnin the experimental plots were located on peat meadow. Table 1 and 2 present soil characteristics and mineral fertilizers used.

In the research the amount of seeds of the grass sown varied depending on the variety and the location of the experiment. It was as follows (in $\mathrm{kg} \cdot \mathrm{ha}^{-1}$ ): Dactylis glomerata - Tukan: 16.3; Amila: 17.5; Crown Royale: 18.8 (Krzyżewo) and 17.6 (Uhnin); Niva: 18.3, Festuca praten- sis - Pasja: 28.7; Limosa: 29.8 (Krzyżewo) and 27.1 (Uhnin); Anturka: 26.6; Amelka: 27.8 (Krzyżewo) and 27.9 (Uhnin).

The sowing dates for Dactylis glomerata were 22 April 2011 (Krzyżewo), 6 May 2011 (Uhnin) for Festuca pratensis 22 May 2011 (Krzyżewo) and 29 April 2011 (Uhnin).

In the year when the experiment was set up the grass was not harvested and only weeds were mowed. According to the guidelines of Research Centre for Cultivar Testing in Słupia Wielka, the full exploitation of Dactylis glomerata varieties was due between 2012 and 2013, whereas for Festuca pratensis it was due between 2011 and 2012. In the experimental plots with the varieties of Dactylis glomerata the grass was harvested six times a year and chemical analysis of the biomass was done taking dry matter only from five cuts. The varieties of Festuca pratensis were harvested four times. Each year in the course of the experiment fresh and dry matter of each cut were weighed. Research Centre for Cultivar Testing in Stupia Wielka made those measurements available to be used in this paper.

Statistical analysis of the data was done using Statistica 6.0 - 2001, with multifactorial analysis of variance. Tukey's test was used to find means that were significantly different from each other with level of significance $p \leq 0,05$.

Climatic conditions of the area where the experiment was carried out are typical for the 9th agricultural and climatic eastern part of Poland. The average annual air temperature varies from 6.7 to $6.9^{\circ} \mathrm{C}$ and in the summer season the average 24 hour temperature is $15{ }^{\circ} \mathrm{C}$. The growing season usually starts on 28 March, lasts till 30 October and is 200 to 220 days long [Radzka 2014]. The average climatic water balance during the time of the experiment varied considerably according to the period and location. Annual

Table 1. Soil conditions

\begin{tabular}{|c|c|c|c|c|}
\hline Grass & \multicolumn{2}{|c|}{ Dactylis glomerata } & \multicolumn{2}{c|}{ Festuca pratensis } \\
\hline Location & Krzyżewo & Uhnin & Krzyżewo & Unnin \\
\hline \multicolumn{5}{|c|}{ Soil conditions } \\
\hline The value of soil according to IUNG & 52 & 50 & 52 & 70 \\
\hline Agricultural value & 5 & $1 \mathrm{p}$ & 5 & $1 \mathrm{z}$ \\
\hline Type & $\mathrm{P}$ & $\mathrm{PS}$ & $\mathrm{P}$ & $\mathrm{PS}$ \\
\hline Texture & $\mathrm{I}$ & - & $\mathrm{Is}$ & - \\
\hline $\mathrm{pH}$ & 6.7 & 5.5 & 6.7 & 5.5 \\
\hline
\end{tabular}

Symbols: $1 \mathrm{p}$ - good and very good permanent meadow, 5 - good quality rye soil; P - podsolic soil, PS - peaty soil, ls - loamy sand. 
Table 2. Mineral fertilizers used in the experiment with varieties of Dactylis glomerata and Festuca pratensis

\begin{tabular}{|l|c|c|c|c|}
\hline \multicolumn{5}{|c|}{ Fertilizers $\left[\mathrm{kg}^{-h^{-1}}\right.$ ] } \\
\hline Nitrogen - N: & & & & \\
- before sowing, & 270 & 80 & 80 & 80 \\
- in consecutive years & 245 & 192 & & \\
\hline Phosphorus $-\mathrm{P}_{2} \mathrm{O}_{5}:$ & & & & \\
- before sowing, & 90 & 100 & 80 & 80 \\
- in consecutive years & 80 & 100 & & \\
\hline Potas - $\mathrm{K}_{2} \mathrm{O}$ : & & & & \\
- before sowing, & 90 & 100 & 100 & 100 \\
- in consecutive years & 130 & 110 & & \\
\hline
\end{tabular}

rainfall ranges from 550 to $650 \mathrm{~mm}$, with not frequent but recurrent rain. Water stress was mainly observed in spring while water deficit occurred in July [Radzka 2014].

During the time of the experiment weather data were provided by the Meteorological and Hydrological Stations in Krzyżew and Uhnin. To determine temporal variation of meteorological parameters and their impact on plant growth Sielianinov's hydrothermal index was used [Bac et al. 1993] with the month's classification according to Skowera and Puła [2004]. As it can be seen from table 3 space-time distribution of annual rainfall varied. April was a month of water stress only in 2011 in Krzyżewo $(\mathrm{K}=0.86)$, whereas in May water deficit was noted in Uhnin in $2012(\mathrm{~K}=0,84)$. Every year in June there was enough rain both in Krzyżewo and Uhnin ( $\mathrm{K}$ between 1.06 and 2.12). July was either extremely wet (Krzyżewo $2011 \mathrm{~K}=3,9$, Uhnin $\mathrm{K}=3,03$ ) or dry (Krzyżewo and Uhnin 2013). However, on the whole both July and August were rather dry whereas September and October happened to be extremely dry one year each with Sielianinov's hydrothermal index more that 4 (Krzyżewo 2013 and Uhnin 2012).

\section{RESULTS AND DISCUSSION}

For all varieties and both locations during those three years when the experiment was done (Table 4 and 5) the average annual yield of six cuts of Dactylis glomerata was $14.7 \mathrm{t} \cdot \mathrm{ha}^{-1}$ of dry matter. In the case of Festuca pratensis the annual average yield in Krzyżewo (mineral soil) was $23.5 \%$ higher than in Uhnin (organic soil). Moreover, the statistical analysis proved that means of the main effect and interaction were significantly different.

The variety of Festuca pratensis with the highest yield of biomass was Amelka (16.3 $\mathrm{t} \cdot \mathrm{ha}^{-1}$ of dry matter) whereas Limosa gave the lowest yield of $14,8 \mathrm{t} \cdot \mathrm{ha}^{-1}$ of dry matter. It is worth noting that the yields of Dactylis glomerata were not significantly different.

Rutkowska and Lewicka [1991] as well as Kozłowski and Swędrzyński [1997] did not find significant differences in yield between varieties of Dactylis glomerata. The same publications say the average yield of Dactylis glomerata is much lower (between 8.51 and $9.60 \mathrm{t} \cdot \mathrm{ha}^{-1}$ of dry matter). Observation of yields of Dactylis glomerata and Festuca pratensis in particular cuts (Table 6 and 7) shows that with six mowings of Dactylis glomerata the highest yield (on average $2.99 \mathrm{t} \cdot \mathrm{ha}^{-1}$ of dry matter) was form the fifth cut of the grass, while the lowest from the sixth (1,63 $\mathrm{t} \cdot \mathrm{ha}^{-1}$ of dry matter).

Many publications [Kallenbach et al. 2002, Wilczek, Ćwintal 2002; Kochanowska-Bukows-

Table 3. Sielianinov's hydrothermal index $(\mathrm{K})$ during the growing season in the years of the experiment in Krzyżewo and Uhnin

\begin{tabular}{|c|c|c|c|c|c|c|}
\hline \multirow{3}{*}{ Month } & \multicolumn{3}{|c|}{ Krzyżewo } & \multicolumn{3}{|c|}{ Uhnin } \\
\hline & \multicolumn{6}{|c|}{ Year of experiment } \\
\hline & 2011 & 2012 & 2013 & 2011 & 2012 & 2013 \\
\hline IV & $0.86(s)$ & $1.63(d w)$ & $2.50(w)$ & 1.39 (o) & 1.06 (ds) & $2.79(\mathrm{bw})$ \\
\hline V & $1.64(\mathrm{dw})$ & 1.09 (ds) & $1.80(\mathrm{dw})$ & 1.09 (ds) & $0.84(s)$ & $2.87(\mathrm{bw})$ \\
\hline $\mathrm{VI}$ & $1.06(\mathrm{ds})$ & $1.83(\mathrm{dw})$ & $1.53(0)$ & $2.12(w)$ & $1.92(\mathrm{dw})$ & $1.74(\mathrm{dw})$ \\
\hline VII & $3.90(\mathrm{sw})$ & $1.55(\mathrm{o})$ & 1.08 (ds) & $3.03(\mathrm{sw})$ & $0.81(\mathrm{~s})$ & $0.92(s)$ \\
\hline VIII & 1.15 (ds) & $3.18(\mathrm{sw})$ & $0.89(\mathrm{~s})$ & 0.79 (s) & 1.25 (ds) & 0.12 (ss) \\
\hline IX & 0.41 (bs) & 0.40 (ss) & $4.84(\mathrm{sw})$ & 0.21 (ss) & $0.79(\mathrm{~s})$ & $2.46(w)$ \\
\hline$x$ & $0.81(\mathrm{~s})$ & $2.27(w)$ & 0.48 (bs) & 1.27 (ds) & 4.90 (sw) & 0.46 (bs) \\
\hline
\end{tabular}

Note: (ss) - extremely dry, (bs) - very dry, (s) - dry, (ds) - quite dry, (o) - optymal, (dw) - quite wet, (w) - wet, (bw) - very wet, (sw) - extremely wet. 
Table 4. Annual yield of Dactylis glomerata in $t \cdot h a^{-1}$ of dry matter according to the year, variety and location

\begin{tabular}{|c|c|c|c|c|}
\hline \multirow{2}{*}{ Variety } & \multirow{2}{*}{ Year } & \multicolumn{2}{|c}{ Location } & \multirow{2}{*}{ Mean } \\
\cline { 2 - 5 } & & Krzyżewo & Uhnin & 16.18 \\
\hline \multirow{2}{*}{ Niwa } & 2012 & 17.68 & 14.68 & 13.31 \\
\cline { 2 - 5 } & 2013 & 11.54 & 15.09 & 16.61 \\
\hline \multirow{2}{*}{ Tukan } & 2012 & 18.54 & 14.68 & 13.19 \\
\cline { 2 - 5 } & 2013 & 11.47 & 14.96 & 15.56 \\
\hline \multirow{2}{*}{ Amila } & 2012 & 16.80 & 14.32 & 12.71 \\
\cline { 2 - 5 } & 2013 & 11.31 & 14.12 & 16.66 \\
\hline \multirow{2}{*}{ Crown Royale } & 2012 & 18.37 & 14.95 & 13.39 \\
\hline \multicolumn{2}{c}{ Niva } & 11.91 & 14.87 & 14.74 \\
\hline Tukan & 2013 & 14.61 & 14.88 & 14.90 \\
\hline Amila & 14.98 & 14.82 & 15.13 \\
\hline Crown Royale & 14.05 & 14.22 & 15.02 \\
\hline Mean & 15.14 & 14.21 & 14.70 & \\
\hline
\end{tabular}

$\mathrm{NIR}_{0,05}$ for: location $\times$ year $\times$ variety $-\mathrm{NS}$ (not significant); variety $\times$ year $-\mathrm{NS}$; location $\times$ variety - NS; variety - NS; location - NS.

Table 5. Annual yield of Festuca pratensis in $\mathrm{t} \mathrm{ha}^{-1}$ of dry matter according to the year, variety and location

\begin{tabular}{|c|c|c|c|c|}
\hline \multirow{2}{*}{ Variety } & \multirow{2}{*}{ Year } & \multicolumn{2}{|c|}{ Location } & \multirow{2}{*}{ Mean } \\
\hline & & Krzyżewo & Uhnin & \\
\hline \multirow{2}{*}{ Limosa } & 2011 & 20.3 & 13.6 & 17.00 \\
\hline & 2012 & 11.0 & 11.37 & 11.19 \\
\hline \multirow{2}{*}{ Pasja } & 2011 & 21.0 & 13.6 & 17.30 \\
\hline & 2012 & 14.6 & 10.64 & 12.62 \\
\hline \multirow{2}{*}{ Anturka } & 2011 & 21.2 & 13.5 & 17.40 \\
\hline & 2012 & 14.6 & 10.93 & 12.77 \\
\hline \multirow{2}{*}{ Amelka } & 2011 & 20.8 & 14.3 & 17.60 \\
\hline & 2012 & 15.0 & 12.12 & 13.56 \\
\hline \multicolumn{5}{|c|}{ Variety mean } \\
\hline \multicolumn{2}{|c|}{ Limosa } & 15.70 & 12.49 & 14.10 \\
\hline \multicolumn{2}{|c|}{ Pasja } & 17.80 & 12.12 & 14.96 \\
\hline \multicolumn{2}{|c|}{ Anturka } & 17.90 & 12.22 & 15.05 \\
\hline \multicolumn{2}{|c|}{ Amelka } & 17.90 & 13.21 & 15.50 \\
\hline \multicolumn{2}{|c|}{ Mean } & 17.30 & 12.52 & \\
\hline
\end{tabular}

$\mathrm{NIR}_{0,05}$ for: location $\times$ year $\times$ variety -2.7 ; variety $\times$ year $-\mathrm{NS}$; location $\times$ variety -1.6 ; variety -1.3 ; location -3.1

ka 2003, Gaweł 2005, Mastalerczuk 2007, Nowak, Sowiński 2007] say that the number of grass cuts affects yield and content of nutrients of the fodder but also influences the concentration of some macro elements. To determine the nutritional value of the feed the balance between nutrients is important because a lack of such balance may deteriorate nutrient utilization and lead to metabolic disorders in animals [Urban et al. 2003, Nowak, Sowiński
2007, Mastalerczuk 2007, Gaweł 2009]. In the plots with Festuca pratensis, no matter what variety or location, with four mowings there were significant differences in yield. The considerable proportion of the annual yield, over $37.5 \%$, was the first mowing in spring (5.75 $\mathrm{t} \cdot \mathrm{ha}^{-1}$ of dry matter). There were no significant differences between mowings 2, 3 and 4, with the lowest yield of the second cut of $2.71 \mathrm{t} \cdot \mathrm{ha}^{-1}$ of dry matter. 
Table 6. Yield of dry matter [t.ha $\left.\mathrm{t}^{-1}\right]$ of Dactylis glomerata according to a cut and location (average from all the years of the experiment)

\begin{tabular}{|c|c|c|c|c|}
\hline \multirow{2}{*}{ Variety } & \multirow{2}{*}{ Mowing } & \multicolumn{2}{|c|}{ Location } & \multirow{2}{*}{ Mean } \\
\hline & & Krzyżewo & Uhnin & \\
\hline \multirow{6}{*}{ Niva } & 1 & 2.64 & 2.83 & 2.74 \\
\hline & II & 2.23 & 1.86 & 2.05 \\
\hline & III & 2.85 & 2.28 & 2.57 \\
\hline & IV & 3.15 & 2.78 & 2.97 \\
\hline & V & 3.04 & 3.43 & 3.24 \\
\hline & $\mathrm{VI}$ & 1.08 & 1.76 & 1.42 \\
\hline \multirow{6}{*}{ Tukan } & I & 2.53 & 2.90 & 2.72 \\
\hline & II & 2.18 & 1.94 & 2.06 \\
\hline & III & 2.59 & 2.26 & 2.43 \\
\hline & IV & 3.03 & 2.81 & 2.92 \\
\hline & V & 2.73 & 3.05 & 2.89 \\
\hline & VI & 1.01 & 1.61 & 1.31 \\
\hline \multirow{6}{*}{ Amila } & I & 2.72 & 3.12 & 2.92 \\
\hline & II & 2.21 & 2.07 & 2.14 \\
\hline & III & 2.70 & 2.22 & 2.46 \\
\hline & IV & 3.10 & 2.65 & 2.88 \\
\hline & V & 2.83 & 2.90 & 2.87 \\
\hline & VI & 1.07 & 1.87 & 1.47 \\
\hline \multirow{6}{*}{$\begin{array}{l}\text { Crown } \\
\text { Royale }\end{array}$} & I & 3.12 & 3.12 & 3.12 \\
\hline & II & 2.12 & 1.68 & 1.90 \\
\hline & III & 2.68 & 2.10 & 2.39 \\
\hline & IV & 1.54 & 2.98 & 2.26 \\
\hline & V & 2.81 & 3.13 & 2.97 \\
\hline & $\mathrm{VI}$ & 2.31 & 1.87 & 2.09 \\
\hline \multicolumn{5}{|c|}{ Mowing means } \\
\hline & & 2.75 & 2.99 & 2.87 \\
\hline & & 2.19 & 1.89 & 2.04 \\
\hline & & 2.71 & 2.22 & 2.47 \\
\hline & & 2.70 & 2.81 & 2.76 \\
\hline & & 2.85 & 3.13 & 2.99 \\
\hline & & 1.47 & 1.78 & 1.63 \\
\hline
\end{tabular}

$\mathrm{NIR}_{0,05}$ for: location $\times$ mowing $\times$ variety -0.29 ; variety $\times$ mowing -0.27 ; mowing $\times$ location -0.30 ; mowing -0.26

\section{CONCLUSIONS}

1. The grass species and their varieties as well as the particular mowing and kind of soil where the grass was grown have an impact on the yield.

2. On mineral soil, the yield of Dactylis glomerata was higher than Festuca pratensis. On organic soil, the yield of both species was similar.
Table 7. Yield of dry matter $\left[\mathrm{t} \cdot \mathrm{ha}^{-1}\right]$ of Festuca pratensis according to a cut and location (average from all the years of the experiment)

\begin{tabular}{|c|c|c|c|c|}
\hline \multirow{2}{*}{ Variety } & \multirow{2}{*}{ Mowing } & \multicolumn{2}{|c|}{ Location } & \multirow{2}{*}{ Mean } \\
\hline & & Krzyżewo & Uhnin & \\
\hline \multirow{4}{*}{ Limosa } & I & 7.10 & 4.21 & 5.66 \\
\hline & II & 2.06 & 3.22 & 2.64 \\
\hline & III & 4.52 & 3.74 & 4.13 \\
\hline & IV & 3.79 & - & 3.79 \\
\hline \multirow{4}{*}{ Pasja } & I & 7.14 & 4.03 & 5.59 \\
\hline & II & 2.11 & 3.31 & 2.71 \\
\hline & III & 4.58 & 3.37 & 3.98 \\
\hline & IV & 3.99 & - & 3.99 \\
\hline \multirow{4}{*}{ Anturka } & 1 & 7.23 & 3.93 & 5.58 \\
\hline & II & 2.24 & 3.32 & 2.78 \\
\hline & III & 4.51 & 3.57 & 4.04 \\
\hline & IV & 3.92 & - & 3.92 \\
\hline \multirow{4}{*}{ Amelka } & I & 7.64 & 4.69 & 6.17 \\
\hline & II & 2.04 & 3.34 & 2.69 \\
\hline & III & 4.30 & 3.78 & 4.04 \\
\hline & IV & 3.93 & - & 3.93 \\
\hline \multicolumn{5}{|c|}{ Mowing means } \\
\hline & & 7.28 & 4.22 & 5.75 \\
\hline & & 2.11 & 3.31 & 2.71 \\
\hline & & 3.33 & 3.62 & 3.48 \\
\hline & & 3.91 & - & 3.91 \\
\hline
\end{tabular}

$\mathrm{NIR}_{0,05}$ for: location $\times$ mowing $\times$ variety -2.60 ; variety $\times$ mowing -1.25 ; mowing $\times$ location -1.1 ; mowing -2.10

3. During the two years of experiment the highest yield among Festuca pratensis varieties was noted for Amelka, whereas among varieties of Dactylis glomerata the yield was similar and differences were not statistically significant.

\section{REFERENCES}

1. Bac S., Koźmiński C., Rojek M., 1993. Agrometeorologia. PWN, Warszawa, 32-33.

2. Borawska-Jarmułowicz B. 2006. Zróżnicowanie fenologiczne odmian Dactylis glomerata wysianych w dwóch rozstawnych rzędach w 3-letnim okresie użytkowania. Łąkarstwo w Polsce., 9, 19-32.

3. Borawska-Jarmułowicz B. 2011. Zróżnicowanie morfologicznych i biologicznych cech odmian Dactylis glomerata w uprawie na nasiona na tle warunków pogodowych Łąkarstwo w Polsce., 14, 23-41.

4. Czyż H, Kitczak T., Stelmaszyk A. 2012. Przydatność Festuca pratensis i Trifolium pratense do podsiewu łąki na glebie organicznej. Folia 
Pomer. Univ. Technol. Stetin. 2012, Agric., Aliment., Pisc., Zootech. 300 (24), 33-42.

5. Domański P. 1998. Metodyka badania wartości gospodarczej odmian (WGO) roślin uprawnych. COBORU, Słupia Wielka., Wyd. I, 1-35.

6. Domański P.J. 1997. Osiągnięcia krajowej hodowli wieloletnich roślin pastewnych straconym czynnikiem intensyfikacji produkcji pasz. Biul. Oceny Odm., 29, 47-58.

7. Gaweł E. 2005. Plonowanie i wartość pokarmowa mieszanek lucerny z kupkówką pospolitą i esparcetą w warunkach różnych systemów wypasania. Pam. Puł., 140, 311-329.

8. Gaweł E. 2009. Skład chemiczny mieszanek wielogatunkowych z lucerną w zależności od częstości koszenia. Fragm. Agron., 26(4), 28-37.

9. Grzegorczyk S., Gołebiewska A. 2004. Kształtowanie się zawartości niektórych składników mineralnych w Lolium perenne L. i Festuca pratensis L. uprawianych w siewie czystym i mieszankach z Plantago lanceolata L . L. Ann. UMCS, Sectio E, 59(1), 457-460.

10. Kallenbach R.I., Nelson C.J., Coutts J.H. 2002. Yield, quality, and persistence of grazing - and hay - type alfalfa under three harvest frequencies. Agron. J., 94, 1094-1103.

11. Kasperczyk M., 1994. Reakcja zbiorowisk kupkówki pospolitej i tymotki łąkowej na ekstensyfikację nawożenia mineralnego. Problemy Zagospodarowania Ziem Górskich, 37, 143-152.

12. Kochanowska-Bukowska Z. 2003. Wstępna ocena przydatności niektórych gatunków traw do mieszanek z lucerna siewną (Medicago sativa L.) Legend na użytki przemienne. Biul. IHAR, 225, 221-228.

13. Kozłowski S., Swędrzyński A. 1997; Żywotność odmian hodowlanych kupkówki pospolitej (Dactylis glomerata). Biuletyn Oceny Odmian, 28, 103-112.

14. Mastalerczuk G. 2007. Zawartość składników pokarmowych w organach roślin łąkowych w warunkach różnej intensywności użytkowania. Łąk. Pol., 9, 131-140.

15. Nowak W., Sowiński J. 2007. Wpływ podziału dawki azotu i doboru komponentów traw do mieszanek z koniczyną czerwoną na plonowanie i skład chemiczny. Cz. II. Skład chemiczny. Zesz. Probl. Post. Nauk Rol., 516, 129-135.

16. Radzka E. 2014. Klimatyczny bilans wodny okresu wegetacyjnego (według wzoru Iwanowa) w środkowowschodniej Polsce. Woda-Środowisko-Obszary Wiejskie, 14, 1(45), 67-76.

17. Rutkowska B., Lewicka E., 1991. Trwałość i plonowanie wybranych gatunków i odmian traw w naturalnych siedliskach łąkowych. Biul. Oceny Odm., 23, 41-50.

18. Rutkowska B., Bukowiecki F.K., Kamiński J. 1994. Wykorzystanie odmian traw i motylkowatych w łąkarstwie. In: Mat. Konf. Nauk. "Hodowla i nasiennictwo rośli na potrzeby użytków zielonych". SITWM, MRiGŻ, IMUZ, Olsztyn, 36-48.

19. Skowera B., Puła J. 2004. Skrajne warunki pluwiotermiczne w okresie wiosennym na obszarze Polski w latach 1971-2000. Acta Agroph., 3(1), 171-177.

20. Urban D., Mikosz A.I., Michalska R. 2003. Zawartość makroelementów w glebach i roślinności łąkowej wybranych obiektów torfowiskowych Poleskiego Parku Narodowego. Annales UMCS, Sec. E., 58, 167-175.

21. Wilczek M., Ćwintal M. 2002. Wpływ liczby pokosów i odmian różnego pochodzenia na plonowanie oraz jakość lucerny. Cz. I. Plon, jego struktura i wydajność białka. Acta Sci. Pol. Agricultura, 1(2), 131-140. 